\title{
Interaction of Energy Storage Technologies and Synthetic Fuels in Long-Term Decarbonization Scenarios
}

\author{
Diana Böttger \\ Fraunhofer Institute for Energy \\ Economics and Energy System \\ Technology IEE \\ Kassel, Germany \\ diana.boettger@iee.fraunhofer.de \\ Christoph Kost \\ Fraunhofer Institute for Solar Energy \\ Systems ISE \\ Freiburg, Germany \\ christoph.kost@ise.fraunhofer.de
}

\author{
Benjamin Lux \\ Fraunhofer Institute for Systems and \\ Innovation Research ISI \\ Karlsruhe, Germany \\ benjamin.lux@isi.fraunhofer.de
}

Tobias Fleiter

Fraunhofer Institute for Systems and

Innovation Research ISI

Karlsruhe, Germany

tobias.fleiter@isi.fraunhofer.de

\author{
Benjamin Pfluger \\ Fraunhofer Institute for Systems and \\ Innovation Research ISI \\ Karlsruhe, Germany \\ benjamin.pfluger@isi.fraunhofer.de
}

\author{
Judith Heilig \\ Fraunhofer Institute for Solar Energy \\ Systems ISE \\ Freiburg, Germany \\ judith.heilig@ise.fraunhofer.de
}

\author{
Norman Gerhardt \\ Fraunhofer Institute for Energy \\ Economics and Energy System \\ Technology IEE \\ Kassel, Germany \\ norman.gerhardt@iee.fraunhofer.de \\ Michael Haendel \\ Fraunhofer Institute for Systems and \\ Innovation Research ISI \\ Karlsruhe, Germany \\ michael.haendel@isi.fraunhofer.de
}

\begin{abstract}
With the 2015 Paris Climate Agreement, the international community has reaffirmed its commitment to tackle anthropogenic climate change with the goal of limiting the global average temperature increase below $1.5{ }^{\circ} \mathrm{C}$, but to a maximum of $2{ }^{\circ} \mathrm{C}$ above pre-industrial levels. Against this background, we examine scenarios for a complete decarbonisation of the European energy supply. Since such scenarios are based on a high expansion of weather-dependent renewable energy sources, the question arises, which flexible technologies are necessary to balance supply and demand in such energy systems. In this paper, a scenario analysis shows which capacity or volume of energy storage, power interconnectors and synthetic fuels are needed in decarbonization scenarios. To address this research question three different energy system models are applied. These models cover Europe and Germany, respectively, and are able to explain different results of the single models based of the corresponding model characteristics. The paper concludes that the power sector is able to cover a considerable share of the energy demand in the heat and transport sector with the help of flexible sector coupling technologies such as heat pumps and electric mobility. All considered models manage to find solutions for a deep decarbonization if flexibility and storage option are available.
\end{abstract}

Keywords-Energy Storage, Power-to-X, Decarbonization Scenario, Model comparison

\section{INTRODUCTION}

In order to counter the consequences of climate change, the international community of states agreed in the 2015 Paris Agreement to balance anthropogenic greenhouse gas (GHG) emissions and sinks in the second half of the $21^{\text {st }}$ century [1]. In response, the European Commission (EC) reconfirmed the objective to become GHG neutral by 2050 in the proposal of the first European Climate Law as part of the European Green Deal [2].

Key strategies to reduce GHG emissions that are already agreed upon include increasing energy efficiency measures and substituting fossil fuels with renewable energy sources (RES) $[3,4]$. Solar and wind energy are expected to become the most important generation technologies in the electricity sector due to their generation potential and relatively low cost [5]. The weather dependency of these energy sources increases the need for flexibility options to balance electricity supply and demand at all times [6,7]. There is a common understanding that through electrification of appliances, a decarbonized electricity system can be the basis for emission reductions in many sectors. However, some energy services such as aviation, long-distance transport or steel production remain difficult to decarbonize [8].

Electricity-based fuels (synthetic or e-fuels) have the potential to address both issues. On the one hand synthetic fuels can serve as long-term electricity storage and are suitable to provide upward and downward flexibility. On the other hand synthetic fuels can be GHG neutral substitutes for fossil fuels in energy services that are difficult to decarbonize.

For reaching very ambitious climate goals, the electricity sector plays a crucial role. Decarbonizing many applications currently relying on fossil fuels requires either a fuel switch to electricity (e.g. the switch from internal combustion engine cars to e-mobility) or switching to a climate neutral fuel. This fuel can be either biogenic (biofuel) or generated from electricity (Power-to-X, PtX). As biomass supply is limited it is clear that most of the energy in a decarbonized energy system will be either electricity or fuels derived from electricity. 
Nevertheless, synthetic fuels compete with a wide range of flexibility options, not only from the electricity sector itself (battery storage, pumped hydro storage, electricity grids) but also from the heat sector (heat pumps, electric boilers, heat storage, combined heat and power (CHP) plants) as well as from the transport sector (electric vehicles, eHighway trucks). Therefore, the central research questions of this paper are:

- Which flexibility options are necessary to balance supply and demand in decarbonized energy systems?

- What role can especially synthetic fuels play as a flexibility option and GHG reduction strategy?

A reduction of GHG emissions to net zero leads to strong interactions between the already complex systems of electricity, heat and transport. Scenario studies and models can be used to address this complexity. They can offer orientation in the possible solution space, help to evaluate political alternative courses of action, and support the decision-making process for efficient decarbonization strategies [9]. The EC's long-term strategic vision for a prosperous, modern, competitive and climate neutral economy for reducing greenhouse gases, e.g. is based on scenario calculations [10].

To some extent, the ambition level of decarbonization scenarios has increased over the last years, especially after the Paris Accord. Before that, many scenarios studies were performed reaching a reduction in GHG emissions of around $80 \%$ compared to 1990 . More ambitions scenarios, aiming for a stronger decrease or even full decarbonization, were performed mostly by NGOs. However, after the Paris Accord, deep decarbonization scenarios came into the focus of studies by governments or the EC.

Nevertheless, in published studies the authors came to different conclusions based on their modeled scenarios. Therefore, the comparison and evaluation of different scenarios requires a lot of knowledge about model characteristics and assumptions. In this paper, we compare different scenarios with different modeling approaches in order to gain a better understanding of the mechanisms of RES integration with different flexibility options and the effects of synthetic fuels.

Table 1 gives an overview of different balancing technologies for RES integration (compare [11]). We are going to focus the analysis on the use of these technologies in three recent studies for the German energy system and try to give a better understanding how these technologies compete with the use of synthetic fuels for GHG reduction.

Table 1. Overview of different balancing technologies for RES integration (based on [11])

\begin{tabular}{|l|c|c|}
\hline \multicolumn{1}{|c|}{ Sector } & Positive residual load & Negative residual load \\
\hline $\begin{array}{l}\text { Power } \\
\text { sector }\end{array}$ & $\begin{array}{c}\text { Controllable plants (e.g. } \\
\text { gas turbines) } \\
\text { Battery storage } \\
\text { (Pumped) Hydro storage } \\
\begin{array}{c}\text { Flexible biogas plants } \\
\text { Demand Side Management } \\
\text { Power import }\end{array}\end{array}$ & $\begin{array}{c}\text { Curtailment } \\
\text { Battery storage } \\
\text { (Pumped) Hydro storage } \\
\text { Demand Side Management } \\
\text { Power export }\end{array}$ \\
\hline $\begin{array}{l}\text { Heating } \\
\text { sector }\end{array}$ & CHP plants & $\begin{array}{c}\text { Heat pumps } \\
\text { Electric boilers }\end{array}$ \\
\cline { 2 - 3 } Transport & \multicolumn{2}{|c|}{ Heat storage (indirect influence) } \\
sector & Vehicle-to-Grid & $\begin{array}{c}\text { Controlled charging of } \\
\text { electric vehicles } \\
\text { Hybrid eHighway trucks }\end{array}$ \\
\hline
\end{tabular}

The remainder of the paper is structured as follows: In section II we explain the analyzed models and scenarios. Section III presents the results of the model and scenario comparison. The paper closes with a summary and conclusion.

\section{MethodOLOGY}

We are going to analyze three different scenarios for a long-term (year 2050) decarbonization scenario for Germany in the European context. The scenarios are the results of three different energy system models ("Enertile", "REMod" and "SCOPE SD"). Table 2 gives an overview of the three models and their main characteristics and Table 3 presents the most relevant scenario assumptions. In the following subsections, the most important model characteristics and scenario assumptions are presented in more detail.

\section{A. Scenario "Enertile - Hydrogen import"}

\section{1) Model description}

The energy system model "Enertile" of Fraunhofer ISI is a cost minimization model for the provision of electricity, heat, and hydrogen $[5,12,13]$. The transport sector is modeled based on results from the simulation model "Aladin" which calculates power and hydrogen demand. The model Enertile can optimize the charging of electric vehicles while eHighway trucks are assumed to be inflexible. The central constraints of the optimization include that exogenously specified demands

Table 2. Overview of model characteristics

\begin{tabular}{|c|c|c|c|}
\hline Criteria/Model & Enertile & REMod & SCOPE SD \\
\hline \multicolumn{4}{|l|}{$\begin{array}{l}\text { General model } \\
\text { charcteristics }\end{array}$} \\
\hline $\begin{array}{r}\text { Programming } \\
\text { technic }\end{array}$ & LP & NLP & LP \\
\hline Time horizont & $\begin{array}{c}\text { Path until } \\
2050 \text { (10 year } \\
\text { steps) }\end{array}$ & $\begin{array}{l}\text { Path until } 2050 \\
\text { (each year) }\end{array}$ & $\begin{array}{l}2050 \text { (single } \\
\text { year) }\end{array}$ \\
\hline Time resolution & Hourly & Hourly & Hourly \\
\hline Spatial scope & Europe & Germany $^{a}$ & Europe \\
\hline \multicolumn{4}{|l|}{$\begin{array}{l}\text { Investment } \\
\text { decision scope }\end{array}$} \\
\hline Power plants & Endogenous & Endogenous & Endogenous \\
\hline Wind and PV & Endogenous & Endogenous & Endogenous \\
\hline Hydro power & Endogenous & Exogenous & Exogenous \\
\hline $\begin{array}{r}\text { Heating } \\
\text { technologies }\end{array}$ & Endogenous & Endogenous & Endogenous \\
\hline Insulation & Exogenous & Endogenous & Exogenous \\
\hline Vehicles & Exogenous & Endogenous & Endogenous \\
\hline $\begin{array}{r}\text { Transmission } \\
\text { capacity }\end{array}$ & Endogenous & Endogenous & Exogenous \\
\hline $\begin{array}{r}\text { Storage } \\
\text { technologies }\end{array}$ & Endogenous & Endogenous & Endogenous \\
\hline $\begin{array}{l}\text { Details of } \\
\text { Thermal } \\
\text { Generation }\end{array}$ & None & $\begin{array}{l}\text { Partial Effi- } \\
\text { ciencies, Start- } \\
\text { up Costs, } \\
\text { Ramping con- } \\
\text { straints, Min. } \\
\text { downtimes and } \\
\text { operating } \\
\text { times, Time- } \\
\text { Dependent } \\
\text { Availabilities }\end{array}$ & $\begin{array}{c}\text { Ramping con- } \\
\text { straints, Time- } \\
\text { Dependent } \\
\text { Availabilities }\end{array}$ \\
\hline
\end{tabular}


Table 3. Overview of scenario assumptions for 2050 with focus on Germany

\begin{tabular}{|r|c|c|c|}
\hline Criteria/Scenario & $\begin{array}{c}\text { Enertile - } \\
\text { Hydrogen } \\
\text { import }\end{array}$ & $\begin{array}{c}\text { REMod - } \\
\text { Sufficiency }\end{array}$ & $\begin{array}{c}\text { SCOPE SD - } \\
\text { PtG/PtL im- } \\
\text { port }\end{array}$ \\
\hline $\begin{array}{l}\text { GHG reduction } \\
\text { goal for the } \\
\text { energy sector }\end{array}$ & $-100 \%$ & $-95 \%$ & $-100 \%$ \\
\hline $\begin{array}{l}\text { Investment costs } \\
\text { (Euro/kWel) }\end{array}$ & 1,298 & 1,335 & 920 \\
\hline Wind onshore & 2,731 & 2,251 & 2,830 \\
\hline Wind offshore & 674 & 481 & 539 \\
\hline Solar PV & &
\end{tabular}

of the different energy forms are met in every hour of a year and that predefined greenhouse gas reduction targets are achieved. The cost minimization considers both capacity expansion and dispatch of relevant generation units and infrastructures to meet the energy demand. The geographical scope of Enertile covers Europe including the Western Balkans and the Baltic States. The energy system is modeled in an hourly resolution for the years 2020, 2030, 2040, and 2050 with path dependency. Enertile is a linear, deterministic model and uses perfect foresight.

In order to investigate the challenges for European high decarbonization scenarios, one focus of the modeling in Enertile is the detailed determination of potentials of fluctuating RES. The determination of RES potentials is based on merging technical information of possible generation units with land availability and historical weather data on a grid with an edge length of $10 \mathrm{~km}$. A second focus of the modelling is the representation of flexibility options in systems with high shares of RES. In addition to storages for different energy forms, flexible charging of battery electric vehicles and European power transmission grids, the interactions between the systems electricity, heat, and hydrogen are considered in detail.

\section{2) Scenario assumptions}

The scenario "Enertile - Hydrogen import" is a target scenario with a total GHG reduction of $95 \%$ in Europe in 2050 meaning a complete decarbonisation of the energy sector. The main strategy of this scenario is to switch applications in the demand sectors to direct use of electricity or hydrogen where possible. The use of gaseous or liquid hydrocarbons is limited to the available potential from biogenic sources.

Hydrogen can be generated in Germany or other European countries, but it can also be imported from outside of Europe. For the imports no distinction is made between "green hydrogen" from electricity and "blue hydrogen" from fossil sources. The import price decreases to 55 Euro/MWh in 2050. It seem reasonable, that at this price "green hydrogen" imports are economically feasible, for example from Northern Africa.

The installed nuclear power generation capacity in Europe follows an exogenously defined reduction path that reflects current political decisions and expectations and decreases to about 55 GW in Europe in 2050.

Major assumptions for Germany are:

- The conventional electricity consumption decreases to 477 TWh due to efficiency gains.
- Hydrogen can serve two different purposes in the model. On the one hand, hydrogen can be used as energy storage for the conversion sector. Enertile decides endogenously on the capacities and dispatch of these hydrogen storage systems. On the other hand, electrolysers can be built by the model to meet hydrogen demand from the demand sectors. The demand for hydrogen is partly exogenously predefined and partly result of the optimization. The exogenously determined hydrogen demand in this scenario is dominated by the industry with about 145 TWh.

- Capacity expansion and dispatch of net transfer capacities between neighboring countries is associated with cost and determined endogenously by the model.

- The transport sector is characterized by a high degree of electrification. It is assumed that $50 \%$ of users of battery electric vehicles charge in a controlled way within certain restrictions.

\section{B. Scenario "REMod-Sufficiency"}

\section{1) Model description}

The energy system model "REMod" developed at Fraunhofer ISE calculates a cost optimized German energy system $[14,15]$. Its main idea is to provide a deeper understanding of national energy systems with particular regard to interdependencies between different sectors and energy carriers. All energy carriers and consumer sectors are taken into account, in line with meeting the declared climate targets and ensuring a secure energy supply at all times. By running customized scenario-based simulations, REMod is most suitable to answer specific questions concerning the transformation of large energy systems. The fundamental functionality of REMod is based on a cost-based (non-linear) optimization of a national energy supply system, whose energy-related $\mathrm{CO}_{2}$-emissions do not exceed a specified target value and/or target pathway. The goal of the optimization is to decide on investment and dispatch of all generators, storages, converters, and consumer technologies at minimum costs, such that the energy balance of the overall system is met in every hour from today until 2050. For this purpose, all four consumption sectors transport, industrial process heat demand, electricity demand as well as space heat and domestic hot water are represented. This ensures a detailed depiction of the interdependencies occurring between different sectors and energy carriers and delivers robust suggestions for the transformation pathways of the energy system.

\section{2) Scenario assumptions}

The sufficiency scenario is one of the four main scenarios published in [14]. In this scenario, a $\mathrm{CO}_{2}$ reduction target of $95 \%$ is defined for the energy sector. This means that in this scenario the use of fossil fuels is still possible to a very limited extend. The upper limits for installed renewable energy capacity are $530 \mathrm{GW}_{\mathrm{el}}$ for solar photovoltaics (PV) and $310 \mathrm{GW}_{\mathrm{el}}$ for wind power (on- and offshore). Import and export of electricity is limited to $40 \mathrm{GW}_{\mathrm{el}}$ in 2050 . In this scenario, the influence of sufficiency as main behavioral stream is examined. Sufficiency coupled with strong efforts on energy efficiency lead to a significant reduction of energy consumption. A possible reasoning can be, for example, a changing perspective 
due to the increasing number of extreme events caused by climate change. The central assumptions of the sufficiency scenario are based on [16] and are summarized below:

- Electricity demand: It is assumed that the electricity demand for lighting, cooling, information and communication technology and mechanical energy will decrease by $45 \%$ compared to today's level.

- Transport sector: Based on today's traffic volume, it is assumed that individual and air transport will decrease by $30 \%$ by 2050 . Further, freight transport will remain constant. Overall, the assumption is that vehicles become more efficient and that end users will use their car batteries to balance loads. EHighway-truck are assumed to be inflexible.

- Space heating and hot water: The lower boundary of the renovation rate will be raised from $1 \%$ to $2 \%$ from today's level to 2050 and the upper limit to $3 \%$. The cost optimization chooses the optimal renovation rate between these bounds.

- Industrial process heat: Industrial process heat demand will decrease continuously by $0.75 \%$ per year until 2050

\section{Scenario "SCOPE SD - PtG/PtL import"}

\section{1) Model description}

The optimization model "SCOPE Scenario Development" (SCOPE SD) developed by Fraunhofer IEE determines an energy supply system (power, heat, and transport sector) at minimal cost [17]. The GHG reduction goal to be met can be specified. Security of supply or permanent coverage of demand in all applications and sectors in hourly resolution is guaranteed. It is a linear, deterministic model. The economic optimization can thus calculate the optimal dispatch of power plants based on costs as well as rational investment decisions on the basis of perfect foresight. It is abstracting from today's regulatory framework. The geographical scope of the modeled energy system is Europe without the Balkans. In addition to the electricity and gas market, an overarching market for emission allowances is included. The heat sector encompasses the demand for space heating, domestic hot water and process heat. The transport sector covers an hourly representation of the (within certain limits) flexible power demand of electric vehicles (battery electric, plug-in hybrid, range extender and eHighway trucks). Each of the technologies presented interacts with different markets. For the model, essential input data are the potentials for wind energy and PV, which result from area restrictions and distance regulations. Additionally, temporally and spatially high-resolution time series for the feedin of wind energy and PV are included. The European hydrological power plant park is modeled with historical inflow data for running water, storage water and pumped hydro storage power plants [18].

\section{2) Scenario assumptions}

We analyze a scenario for 2050 with a $95 \%$ GHG reduction goal in Europe. Therefore, energy related GHG-emissions have to be zero.

In Europe, it is assumed that there are in total $12.4 \mathrm{GW}$ of nuclear power plants left in the Czech Republic, Finland, France, and Slovakia (existing plants with 50 years lifetime and few plants that are currently under construction).
For Germany, the most important assumptions are:

- The conventional power demand decreases to $456 \mathrm{TWh}$ due to efficiency increases. In the heating sector, we assume a considerable reduction of final energy demand due to energy-saving measures [19]. The potential for district heating is with $30 \%$ almost three times higher than today.

- While we assume a demand for hydrogen in the industry sector (95 TWh [20]) there is no other technology option for hydrogen (e.g. power production) modeled.

- The transport sector is characterized by a high demand. We assume that $60 \%$ of the electric cars use controlled charging. EHighway trucks are considered as hybrid vehicles with an additional internal combustion engine for times with low RES infeed.

- We assume a comparatively restricted potential of sustainably produced biomass (135 TWh), which is used partly for international transportation, non-energetic purposes but mainly as back up for district heating or industry process heat with few full load hours.

- Concerning power interconnectors in Europe, a capacity of $42 \mathrm{GW}$ between Germany and its neighbors is assumed, which is an exogenous assumption based on [21].

\section{RESULTS}

In the following, we compare the three mentioned scenarios concerning the composition of the energy system and especially the contribution of flexibility from different sectors against the background of the use of synthetic fuels.

\section{A. Power balance}

In 2017, Germany's final energy consumption amounted to 2,560 TWh [22] while it decreases to approximately 1,500 TWh in the analyzed scenarios for 2050 . This is due to efficiency increases (building insulation, heat pumps, and electric engines).

Fig. 1 presents the share of power generation of the single technologies and the power consumption of the different consumer types. In 2017, the net power consumption in Germany was $556 \mathrm{TWh}$ (including grid losses) [23]. The domestic power generation in Germany was $610 \mathrm{TWh}$ [24] of which roughly one third came from RES.

In 2050 in all three scenarios, the power consumption rises to $840-1,050$ TWh due to additional demand from sector coupling technologies. Electricity demand from the heating sector (incl. industry process heat) varies between 150 and $410 \mathrm{TWh}$ and from the transport sector between 90 and $150 \mathrm{TWh}$. Approximately 30 to $210 \mathrm{TWh}$ are used for electrolysis and methanisation. The sufficiency scenario is the only one of the three with net power export to its neighboring countries (59 TWh) while in the other two scenarios the net power import of Germany is between 36 and $75 \mathrm{TWh}$. In the hydrogen import scenario this high import is (among other factors) the result of nuclear power generation in France. 


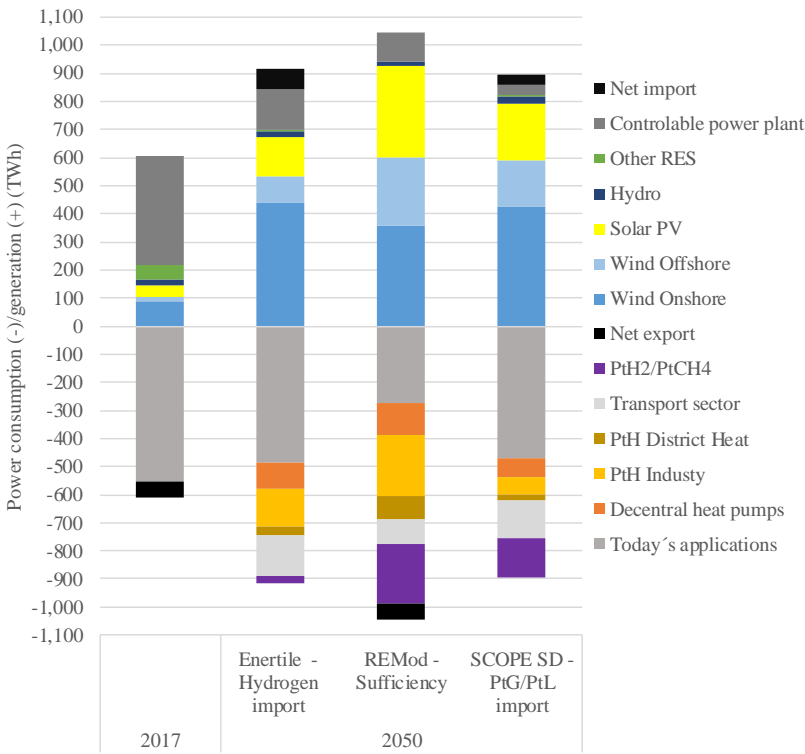

Fig. 1. Power generation and power consumption ( $\mathrm{PtH}$ - Power-to-Heat; historical values from $[23,24])$

Power generation from wind power varies between 530 and 600 TWh and solar PV power generation between 140 and $330 \mathrm{TWh}$. The differences among the power generation of wind and PV in the single scenarios are the result of individual assumptions concerning available potential, full load hours and investment costs (compare Table 2). Power generation from controllable power plants varies between 30 and $140 \mathrm{TWh}$ and is predominately from CHP plants (incl. fuel cells). These plants are fueled by either hydrogen or renewable methane. Only in the sufficiency scenario about one third of the fuel of controllable power plants is fossil methane.

In the Enertile scenario, the option of importing hydrogen has a large impact on the power system. Aside from generation from RES that plays the dominant role in all three scenarios hydrogen reconversion also has a substantial share in power generation. Hydrogen supplies not only peak demand via hydrogen turbines, but CHP plants are additionally used to supply heat grids.

\section{B. Flexibility from the power sector}

In the following, we analyze the scenario differences concerning flexibility that comes from the power sector. First, we compare power storage technologies (battery storage, pumped hydro storage), secondly, we focus on controllable power plants. Thirdly, the curtailment in the scenarios is compared.

Fig. 2 depicts installed capacities of battery storage and pumped hydro storage in Germany. While in 2017 only approximately $0.1 \mathrm{GW}$ battery storage plants were installed [25], the three scenarios have considerably different results concerning battery storage in 2050 ranging from zero to $110 \mathrm{GW}$. In the hydrogen import scenario, battery storage is not cost efficient. In contrast batteries represent a valuable flexible option in the sufficiency scenario. Over $100 \mathrm{GWh}$ of stationary short-term energy storage (e.g. batteries) are used to store electricity from wind and solar PV over a few hours each day. Although the battery storage capacity in the PtG/PtL import scenario is in a comparable range to the sufficiency scenario, the different power-to-capacity relationship offers much higher power in the sufficiency scenario than in the PtG/PtL

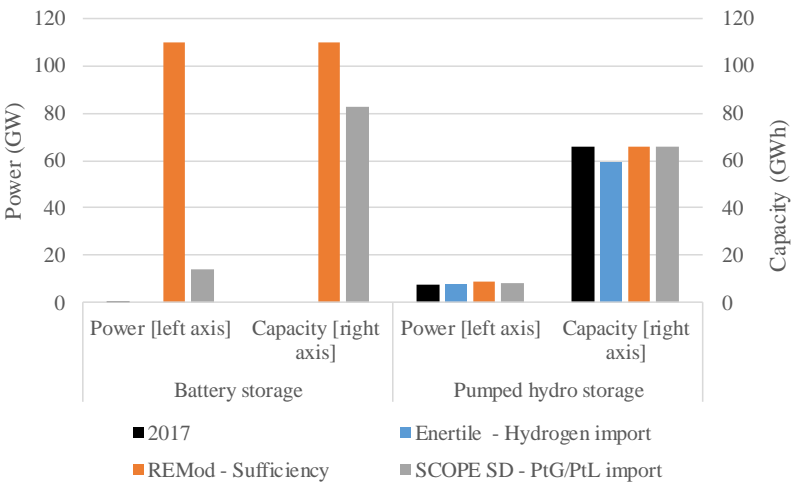

Fig. 2. Installed capacities of battery and pumped hydro storage (historical values from [25])

import scenario. With respect to pumped hydro storage, none of the scenarios reports new plants in Germany. Differences among the installed capacities are only the result of different data sources.

Table 4 reports the installed capacities of controllable power plants in the scenarios. While all controllable power plants in the hydrogen import scenario are fueled by hydrogen, in the PtG/PtL import scenario they are run by nationally produced or imported renewable methane. In the sufficiency scenario, plants are fueled by hydrogen or renewable or fossil methane. Controllable plants reach 870 to 990 full load hours in the sufficiency and the PtG/PtL import scenario while in the hydrogen import scenario they are used twice as much. CHP plants have roughly two to three times higher full load hours than condensing plants or gas turbines without heat extraction.

Table 5 shows the necessary curtailment of RES in the three scenarios. While in the hydrogen import scenario, almost all RES generation can be integrated, in the PtG/PtL import scenario 34.7 TWh or $4.4 \%$ of the RES generation have to be curtailed in Germany. The comparably high curtailment is a result of possible savings of variable cost of wind power plants, the comparably low transfer capacities to other countries (see section III E) and the low battery charging capacity.

The overall results show a relatively low curtailment of renewables due to the optimal design of the energy system with many flexibility options. However, as local grid constraints are not included, it should be assumed that the real curtailment rate could be higher.

Table 4. Controllable power plants

\begin{tabular}{|l|c|c|}
\hline \multicolumn{1}{|c|}{ Scenario } & Capacity (GW) & Full load hours \\
\hline Enertile - Hydrogen import & 78 & 1,832 \\
\hline REMod - Sufficiency & 105 & 990 \\
\hline SCOPE SD - PtG/PtL import & 39 & 872 \\
\hline
\end{tabular}

Table 5. RES Curtailment

\begin{tabular}{|l|c|c|}
\hline \multirow{2}{*}{\multicolumn{1}{|c|}{ Scenario }} & \multicolumn{2}{c|}{ RES Curtailment } \\
\cline { 2 - 3 } & Absolute $(\boldsymbol{T W h})$ & Relative (\%) \\
\hline Enertile - Hydrogen import & 0.2 & $0.0 \%$ \\
\hline REMod - Sufficiency & 9.0 & $1.0 \%$ \\
\hline SCOPE SD - PtG/PtL import & 34.7 & $4.4 \%$ \\
\hline
\end{tabular}




\section{Flexibility from the heating sector}

Several technologies in the heating sector are able to help to integrate fluctuating RES. With respect to district heating grids flexible CHP plants, electric boilers, large-scale heat pumps, fuel back-up boilers and heat storage are important for flexible heat supply. For decentral heat supply heat pumps with heat storage can also operate in a flexible manner.

Fig. 3 depicts the installed capacities of the single technologies for central heat supply. While in the hydrogen import scenario CHP plants are the main heat suppliers and heat pumps deliver another third of heat, heat pumps are the dominant heat supplier in the PtG/PtL import scenario (two third of heat supply). Electric boilers play only a minor role in all scenarios due to the efficiency disadvantage in comparison to heat pumps. Although fuel back up boilers have a comparably high power, their contribution for the heat supply is very low as they are used only in times with low RES supply and very high heat demand. Heat storages also play an important role.

Furthermore, electric heat pumps play a key role for decarbonization of the decentral heat supply. In the three analyzed scenarios there are approximately 12 to 15 mio. heat pumps installed. If they are equipped by a heat storage like in the PtG/PtL import scenario they are able to shift loads between several hours.

\section{Flexibility from the transport sector}

The electrification of the transport sector plays also a central role for the decarbonization in all three scenarios. Possible technologies for direct electrification are battery electric vehicles (preferably with controlled charging) and eHighway trucks. Indirect electrification can be achieved by using hydrogen or PtG/PtL as fuel.

Fig. 4 shows the number of vehicles differentiated by their type. In all scenarios the total number of cars decreases from today 49 mio. to 41 to 45 mio. in 2050 with the lowest number in the sufficiency scenario. While in the hydrogen import and the PtG/PtL import scenario the number of battery electric cars (BEV) lies between 18.5 and 23 mio. The sufficiency scenario counts 29 mio. BEVs what can be explained by the assumed changing user behavior that increases the potential for BEVs. For cases where BEVs are not able to meet the driving demand pattern (e.g. long distances) hybrid cars or cars with either hydrogen or Power-to-liquid (PtL) fuels are used. The highest number of hydrogen cars ( 8 mio.) can be found in the REMod

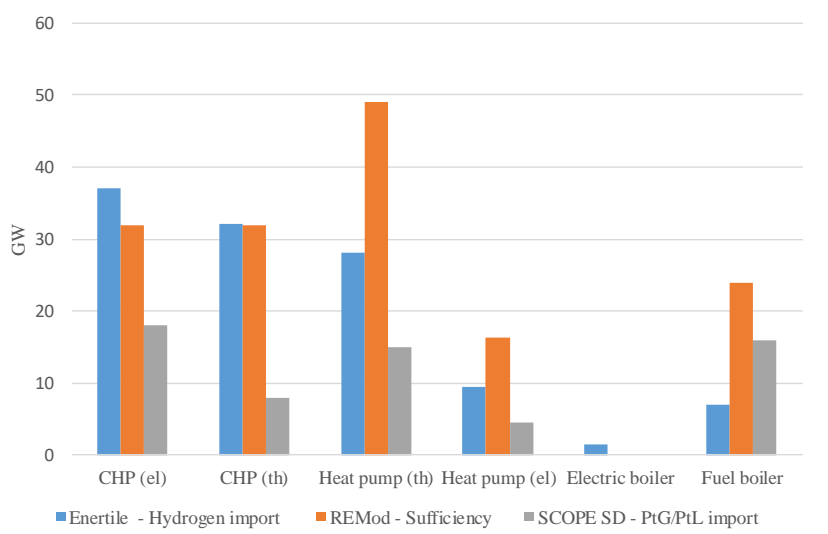

Fig. 3. Capacities of different technologies for central heat supply

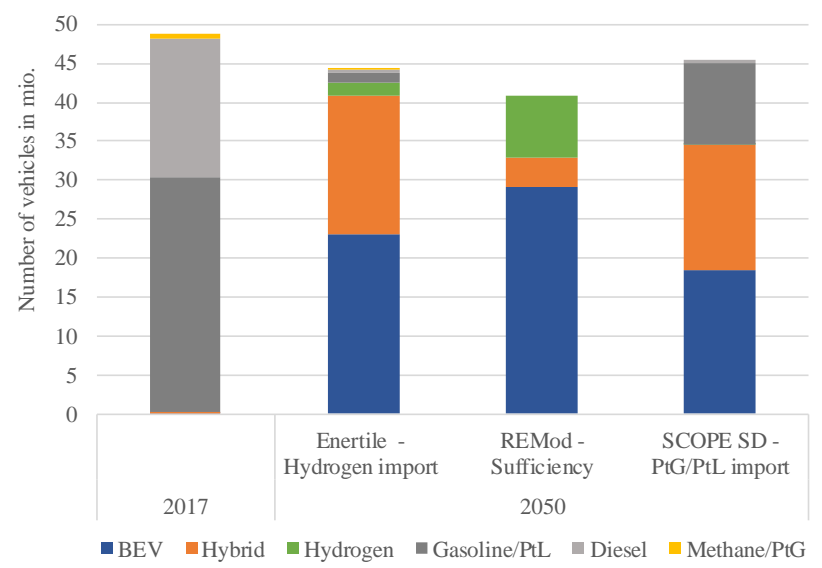

Fig. 4. Composition of the passenger car fleet (BEV: battery electric vehicle, PtL: Power-to-Liquid, PtG: Power-to-Gas; historical values from [26])

scenario. In the SCOPE scenario, cars with PtL (which is imported from outside of Europe) make up 10.5 mio.

\section{E. Flexibility through power exchange with neighbors}

Fig. 5 presents the net transfer capacities of Germany to its electric neighbors in 2017 in comparison to the 2050 scenarios. The transfer capacity increases considerably in all scenarios. The model Enertile is the only model that optimizes transfer capacity endogenously and comes up with $72 \mathrm{GW}$, which is four times today's capacity.

Concerning full load hours of power export we notice a decrease by roughly $50 \%$ from 2017 to 2050 which is also a result of the considerably increasing capacity. All three scenarios for 2050 show export full load hours between 2,000 and 2,500 .

In contrast to the full load hours of the export capacities, the full load hours of power import increase considerably to 3,000 to 3,200 in the hydrogen import and the PtG/PtL import scenario while they decrease in the sufficiency scenario to 325. The electricity import in this scenario is low as neighboring countries do not provide much surplus electricity during hours of high demand in Germany which has to be interpreted against the background of the deviating model formulation in comparison to the other two scenarios. In the hydrogen import scenario the high import is (among other factors) the result of nuclear power generation in France.

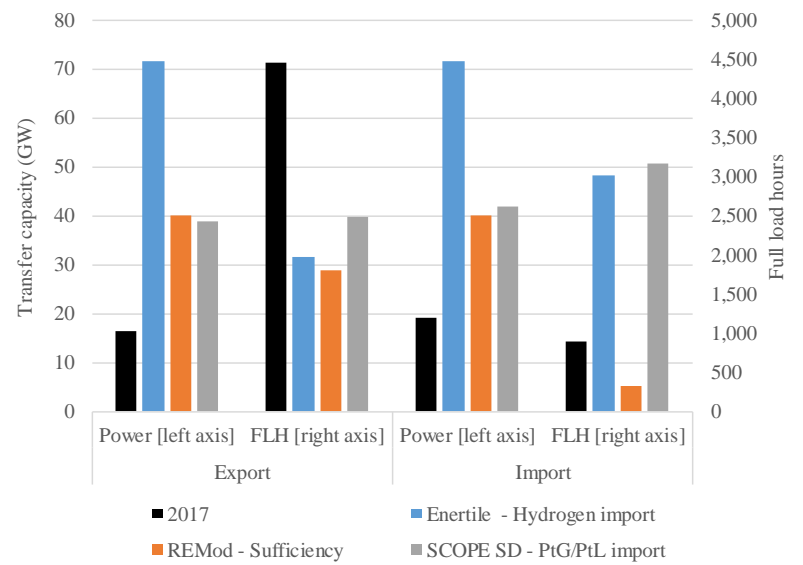

Fig. 5. Net transfer capacities between Germany and its electric neighbors and full load hours (historical values from [27]) 


\section{F. Synthetic fuels}

In the following we analyze the usage of synthetic fuels. We start with hydrogen followed by other fuels like renewable methane and all types of liquid fuels (PtL).

Fig. 6 presents the usage of hydrogen in the three scenarios by different applications. In the hydrogen import scenario the hydrogen consumption is highest (450 TWh) of which more than $95 \%$ are imported. In the sufficiency scenario hydrogen is roughly half imported and half nationally generated. In contrast in the PtG/PtL import scenario nearly all of the hydrogen is nationally produced for industrial applications.

Fig. 7 shows the power consumption, electrolysis capacity and electrolysis full load hours of all scenarios. The electrolysis capacity ranges between 16 and $29 \mathrm{GW}$ in Germany. As in the hydrogen import scenario most of the used hydrogen is imported, national electrolysis has only 1,650 full load hours and operates only in times with very high RES infeed. In contrast, in the other two scenarios the full load hours are between 4,000 and 6,000. In the PtG/PtL import scenario this is due to a high industrial hydrogen demand and the assumption that no national hydrogen grid exists and the hydrogen has to be produced at the industrial site.

Fig. 8 depicts the origin and usage of all other fuels excluding hydrogen. These fuels are mainly used in the transport sector. Only in the PtG/PtL import scenario a considerable share is also consumed in the power and heating sector. In this scenario all these fuels are imported. Only in the sufficiency scenario fossil fuels are still used.

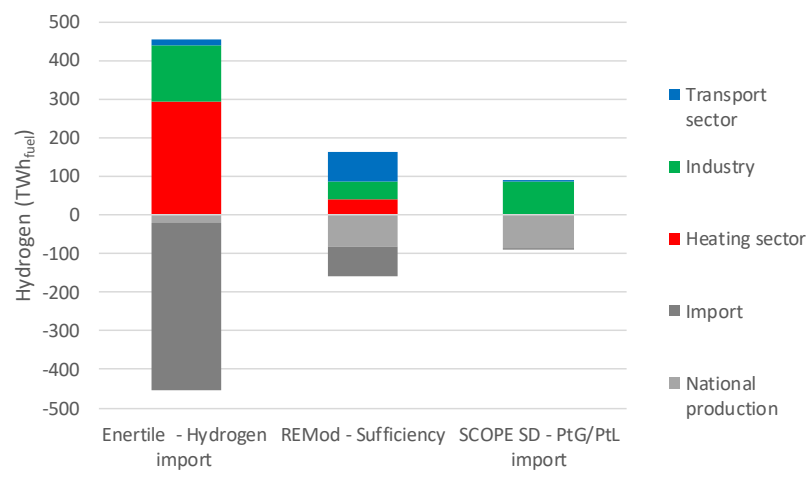

Fig. 6. Hydrogen origin and usage by sector

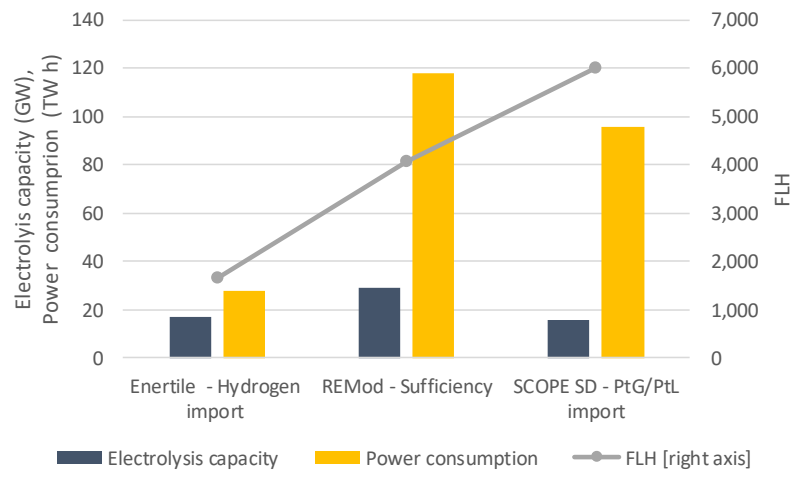

Fig. 7. Details of the usage of German electrolysis plants (FLH: full load

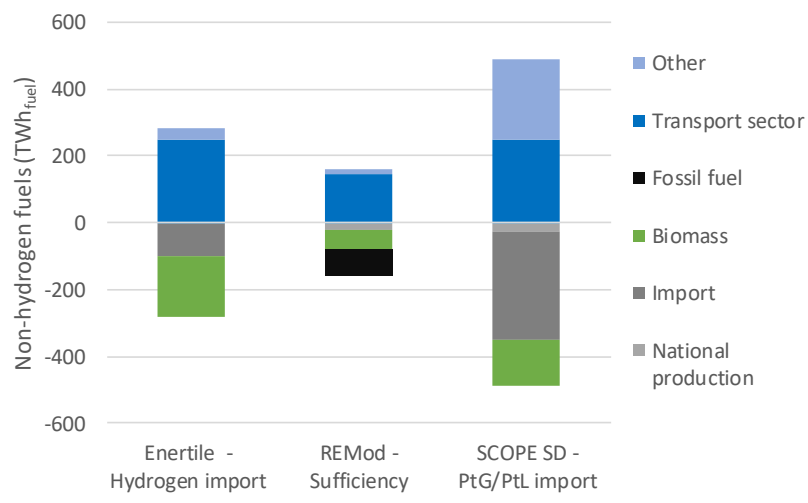

Fig. 8. Non-hydrogen fuels origin and usage by sector

\section{SUMMARY AND CONCLUSIONS}

In this paper, we compared three scenarios for the year 2050 with a carbon neutral energy system in Germany. We found that depending on the assumptions used in the models and in the scenarios some general trends are common while some results vary substantially.

In all scenarios, electricity and fuels derived from electricity become the central pillar of the energy system. Other energy sources (like biomass and geothermal or solar thermal energy) play only a secondary role. For cars and space heating direct electrification through e-mobility and heat pumps becomes dominant in all scenarios; for buildings, district heating also plays a significant role.

The role and fields of application of hydrogen vary between the scenarios, as does its origin. In the SCOPE scenario it is only used for the industry sector, REMod also foresees a use in the transport sectors and in the Enertile scenario it plays a major role in the conversion sector. The generation of the hydrogen through electrolysis also varies substantially, not least in the utilization of the electrolyzers. It seems that in some models the electrolysis is used as a flexibility option, while in other a high utilization of the facilities predominates.

The electricity system has to be constantly in balance. This aspect is captured by all models used in this study at least in an hourly level. Consequentially, the necessary flexibility is fixed; insufficient flexibility would lead to a mismatch of demand and supply with substantial consequences, such as blackouts. In the electricity system of the previous decades flexibility was provided mostly by thermal power plants and (pumped) hydropower. In an electricity system dominated by fluctuating generation from wind and solar energy, additional flexibility options have to be utilized.

The models and scenarios compared in this paper have many options in common, while some options are only used in some models. Key options in all scenarios are:

- interregional and international balancing of RES fluctuations,

- flexible and constantly available power plants; the resulting capacity as well as the fuels used (hydrogen or synthetic methane) varies between the scenarios, though, and 
- flexible power demand (demand side management) from charging of electric vehicles as well as from power-to-heat applications.

Additional sources of flexibility are batteries, which play a substantial role in the SCOPE and REMod scenarios, while they are not cost optimal in the Enertile scenario. All considered models manage to find solutions for a deep decarbonization if flexibility and storage option are available.

\section{ACKNOWLEDGMENT}

This paper was financed by Fraunhofer-Gesellschaft zur Förderung der angewandten Forschung e.V. within its "Cluster of Excellence Integrated Energy Systems" (CINES).

\section{REFERENCES}

[1] United Nations, "Paris Agreement", 2015

[2] European Commission, "Proposal for a REGULATION OF THE EUROPEAN PARLIAMENT AND OF THE COUNCIL establishing the framework for achieving climate neutrality and amending Regulation (EU) 2018/1999 (European Climate Law)" 2020.

[3] European Parliament, Council of the European Union, "DIRECTIVE (EU) 2018/2001 OF THE EUROPEAN PARLIAMENT AND OF THE COUNCIL - of 11 December 2018 - on the promotion of the use of energy from renewable sources" 2018.

[4] European Parliament, Council of the European Union, "DIRECTIVE (EU) 2018/ 2002 OF THE EUROPEAN PARLIAMENT AND OF THE COUNCIL - of 11 December 2018 - amending Directive 2012/ 27/ EU on energy efficiency", 2018.

[5] B. Pfluger, "Assessment of least-cost pathways for decarbonising Europe's power supply: A model-based long-term scenario analysis accounting for the characteristics of renewable energies", Karlsruhe, KIT Scientific Publishing, 2014.

[6] M. Huber, D. Dimkova, T. Hamacher, "Integration of wind and solar power in Europe: Assessment of flexibility requirements", Energy 2014, 69:236-46. doi:10.1016/j.energy.2014.02.109.

[7] H. Kondziella, T. Bruckner, "Flexibility requirements of renewable energy based electricity systems - a review of research results and methodologies", Renewable and Sustainable Energy Reviews 2016 , 53:10-22. doi:10.1016/j.rser.2015.07.199.

[8] S. J. Davis, N. S. Lewis, M. Shaner, S. Aggarwal, D. Arent, I. L. Azevedo et al., "Net-zero emissions energy systems". Science (New York, N.Y.) 2018;360 (6396)

[9] C. Dieckhoff, H.-J. Appelrath, M. Fischedick, A. Grunwald, F. Höffler, C. Mayer et al., "Zur Interpretation von Energieszenarien", Schriftenreihe Energiesysteme der Zukunft, München 2014, Retrieved from

www.akademienunion.de/fileadmin/redaktion/user upload/Publikatio nen/Stellungnahmen/141203 Energieszenarien Web final.pdf

[10] European Commission, "In-depth analysis in support for the commission communication $\operatorname{COM}(2018)$ 773: A European long-term strategic vision for a prosperous, modern, competitive and climate neutral economy", Brussels, 2018.

[11] J. Michaelis, T. Müller, U. Reiter, F. Fermi, A. Wyrwa, Y. Chen, et al., "Comparison of the techno-economic characteristics of different flexibility options in the European energy system". In: 2017 14th International Conference on the European Energy Market (EEM). 6-9 June 2017, Dresden, Germany. 2017: IEEE, pp. 1-5.

[12] B. Pfluger, B. Tersteegen, B. Franke, C. Bernath, T. Bossmann, G. Deac, et al., "Langfristszenarien für die Transformation des Energiesystems in Deutschland: Modul 2: Modelle und Modellverbund" 2017, Retrieved from https://www.bmwi.de/Redaktion/DE/Downloads/B/berichtsmodul-2modelle-und-modellverbund.pdf

[13] G. Deac, "Auswirkungen der Kopplung von Strom- und Wärmemarkt auf die künftige Integration der Erneuerbaren Energien und die $\mathrm{CO}_{2-}$ Emissionen in Deutschland", $\mathrm{PhD}$ thesis, 2020 (in press).

[14] P. Sterchele, J. Brandes, J. Heilig, D. Wrede, C. Kost, T. Schlegl, et al., "Wege zu einem klimaneutralen Energiesystem - Die deutsche
Energiewende im Kontext gesellschaftlicher Verhaltensweisen", Freiburg 2020, Retrieved from https://www.ise.fraunhofer.de/de/veroeffentlichungen/studien/wegezu-einem-klimaneutralen-energiesystem.html

[15] P. Sterchele, "Analysis of Technology Options to Balance Power Generation from Variable Renewable Energy. Case Study for the German Energy System with the Sector Coupling Model REMod", $\mathrm{PhD}$ thesis, Shaker Verlag, 2019. Retrieved from http://publica.fraunhofer.de/documents/N-578059.html

[16] C. Zell-Ziegler and H. Förster, "Mit Suffizienz mehr Klimaschutz modellieren. Relevanz von Suffizienz in der Modellierung, Übersicht über die aktuelle Modellierungspraxis und Ableitung methodischer Empfehlungen", on behalf of Umweltbundesamt, 2018. Retrieved from https://www.umweltbundesamt.de/publikationen/suffizienz-mehrklimaschutz-modellieren

[17] Fraunhofer-Institut für Energiewirtschaft und Energiesystemtechnik, "SCOPE Sektorenübergreifende Einsatz- und Ausbauoptimierung für Analysen des zukünftigen Energieversorgungssystems, 2018, Retrieved

from www.iee.fraunhofer.de/content/dam/iee/energiesystemtechnik/de/Dok umente/Broschueren/2018_F_SCOPE_Einzelseiten.pdf

[18] P. Härtel and M. Korpås, "Aggregation Methods for Modelling Hydropower and Its Implications for a Highly Decarbonised Energy System in Europe", Energies, vol. 10, no. 11, p. 1841, 2017, doi: 10.3390/en10111841.

[19] Fraunhofer-Institut für Energiewirtschaft und Energiesystemtechnik, "Entwicklung der Gebäudewärme und Rückkopplung mit dem Energiesystem in $-95 \%$ THG Klimazielszenarien. Teilbericht im Rahmen des Projektes: Transformationspfade im Wärmesektor Betriebs- und volkswirtschaftliche Betrachtung der Sektorkopplung mit dem Fokus Fernwärme mit hohen Anteilen konventioneller KWKErzeugung und Rückkopplung zum Gesamtenergieversorgungssystem”, Kassel, 2019, Retrieved from https://www.iee.fraunhofer.de/content/dam/iee/energiesystemtechnik/ de/Dokumente/Veroeffentlichungen/2019/2019 Feb Bericht Fraunh ofer IEE - Transformation Waerme 2030 2050.pdf

[20] K. Purr, J. Günther, H. Lehmann, P. Nuss, "Wege in eine ressourcenschonende Treibhausgasneutralität - RESCUE: Langfassung", Climate Change (36/2019), 2019, Dessau-Roßlau, Retrieved from

https://www.umweltbundesamt.de/sites/default/files/medien/376/publ ikationen/rescue_studie_cc_362019 wege in eine ressourcenschonende treibhausgasneutralitaet.p df

[21] Entsoe, “TYNDP 2018”, Retrieved from https://tyndp.entsoe.eu/mapsdatal

[22] AG Energiebilanzen e.V., "Bilanz 2017", Retrieved from https://agenergiebilanzen.de/index.php?article $\mathrm{id}=29 \&$ fileName=bilanz17d.xls

[23] AG Energiebilanzen e.V., "Energieverbrauch in Deutschland im Jahr 2018", Berlin, Bergheim, 2019, Retrieved from https://agenergiebilanzen.de/index.php?article $\mathrm{id}=29 \&$ fileName $=a g e b \_$jahresb ericht2018_20190326_dt.pdf

[24] AG Energiebilanzen e.V., "Stromerzeugung nach Energieträgern 1990 - 2019 (Stand Dezember 2019)", 2019, Retrieved from https://agenergiebilanzen.de/index.php?article id=29\&fileName=agebstrerz2019_18122019.pdf

[25] Bundesnetzagentur für Elektrizität, Gas, Telekommunikation, Post und Eisenbahnen and Bundeskartellamt, "Kraftwerksliste der Bundesnetzagentur - Stand: 11.11.2019”, 2019, Retrieved from https://www.bundesnetzagentur.de/SharedDocs/Downloads/DE/Sachg ebiete/Energie/Unternehmen_Institutionen/Versorgungssicherheit/Erz eugungskapazitaeten/Kraftwerksliste/Kraftwerksliste 2019 2.xlsx? blob=publicationFile \&v=2

[26] Kraftfahrtbundesamt, "Bestand an Kraftfahrzeugen nach UmweltMerkmalen, 1. Januar 2017, Flensburg, Retrieved from https://www.kba.de/SharedDocs/Publikationen/DE/Statistik/Fahrzeug e/FZ/2017/fz13 2017_pdf.pdf? blob=publicationFile\&v=2

[27] Bundesnetzagentur für Elektrizität, Gas, Telekommunikation, Post und Eisenbahnen and Bundeskartellamt, "Monitoringbericht 2019", Bonn, 2020 